\title{
PETA GERAKAN LITERASI DIGITAL DI INDONESIA: STUDI TENTANG PELAKU, RAGAM KEGIATAN, KELOMPOK SASARAN DAN MITRA
}

\author{
Novi Kurnia \\ novikurnia@ugm.ac.id \\ Ilmu Komunikasi Universitas Gadjah Mada \\ Santi Indra Astuti \\ santi.indraastuti@gmail.com \\ Ilmu Komunikasi, Universitas Islam Bandung
}

\begin{abstract}
Abstrack
Digital society nowadays faces various problems such as hoax or fake news, privacy violation, cyberbullying, violence and pornography content, digital media addiction. The question is whether such problems are emerging because of there is no adequate digital literacy in Indonesia? To answer this question, Jaringan Pegiat Literasi Digital (Japelidi, Network of Digital Literacy Activists) conducts a mapping research on digital literacy movement in Indonesia. This study involves 56 researchers from 26 universities in Indonesia. It maps out 342 digital literacy activities conducted in 9 cities in Indonesia. Some research findings are: universities are the main actor in literacy digital movement in Indonesia, public speaking forums are the most frequent digital literacy activities, main target group for digital literacy is the youth and schools are the best partners for digital literacy activities. Based on these findings, the study recommends some suggestions: to increase the digital literacy activities conducted by various actors in Indonesia, to develop various methods of digital literacy programs, to widen the target groups, and to establish relationship with various partners not only schools, but also government, media and corporation. In addition, the study recommend that digital literacy should be implemented in various levels: family, schools, and the state.
\end{abstract}

\begin{abstract}
Abstrak
Beragam persoalan seperti informasi hoaks, pelanggaran privacy, cyberbullying, konten kekerasan dan pornografi, dan adiksi media digital dianggap sebagai persoalan masyarakat digital terkini. Pertanyaannya, apakah problem tersebut muncul karena rendahnya literasi digital di Indonesia? Untuk menjawab pertanyaan tersebut, Jaringan Pegiat Literasi Digital (Japelidi) melakukan pemetaan gerakan literasi digital di Indonesia. Dengan metode desk study dan case study, penelitian melibatkan 56 peneliti dari 28 prodi yang berasal dari 26 perguruan tinggi. Kajian mencakup 342 kegiatan literasi digital di 9 kota di Indonesia memetakan setidaknya 342 kegiatan. Temuan utama penelitian ini antara lain: perguruan tinggi adalah pelaku utama atau motor dalam gerakan literasi digital, sosialisasi adalah kegiatan yang paling sering dilakukan, kaum muda merupakan kelompok sasaran yang paling dominan, dan mitra yang paling adalah sekolah. Penelitian merekomendasikan perlunya lebih banyak pelaku kegiatan yang bukan berasal dari perguruan tinggi, pentingnya mengeksplorasi ragam literasi digital yang bersifat kreatif dan 'empowerment', perlunya memperluas target sasaran literasi digital supaya tidak hanya tertuju pada kaum muda saja, dan pentingnya kemitraan
\end{abstract}


dengan berbagai pihak diperluas dan diperkuat, khususnya dengan pemerintah, media dan korporasi. Selain itu, peneliti merekomendasikan bahwa literasi digital harus diberikan dalam level keluarga, sekolah, dan negara.

Keywords: Digital Literacy, Movement, Mapping.

\section{PENDAHULUAN}

Jumlah pengguna Internet di Indonesia telah mencapai 132.7 juta orang dari 256.2 juta orang populasi Indonesia. Ini berarti, pengguna Internet di Indonesia telah mencapai $51.8 \%$ dari jumlah penduduk Indonesia seluruhnya. Komposisinya bisa dikatakan berimbang di antara laki-laki (52.5\%) dan perempuan (47.5\%). Namun demikian, dari segi geografis, pengguna Internet terbesar berada di pulau Jawa sebanyak 65\% (86.3 juta orang), sisanya tersebar di Sumatera (15.7\%), Sulawesi (6.3\%) dan Kalimantan (5.8\%). Dua wilayah lainnya yaitu Bali dan Nusa persentasenya di bawah $5 \%$. Ini memperlihatkan adanya kesenjangan dalam penggunaan Internet (APJII, 2016).

Kesenjangan juga tampak dari segi usia. Dari keseluruhan pengguna Internet, yang dominan adalah kelompok usia 35-44 tahun sebesar $29.2 \%$, diikuti oleh kelompok usia 25-34 tahun sebanyak 24.4\%. Pada peringkat ketiga, ditempati oleh kelompok usia 10-24 tahun sebanyak $18.4 \%$, diikuti oleh kelompok usia 45-54 tahun sebanyak $18 \%$. Kelompok usia di atas 55 tahun jumlahnya sebanyak $10 \%$. Kelompok usia yang paling produktif, yaitu $25 \mathrm{sd}$. 44 tahun jumlahnya mencapai 53.6\% atau sebanyak 71 juta orang, menjadi pengguna Internet yang paling dominan.

Dari segi profesi, pengguna Internet didominasi oleh kelompok pekerja/wiraswasta sebanyak $62 \%$ atau 82.2 juta orang. Mengejutkan, pada peringkat kedua, ibu rumah tangga menjadi pengguna internet terbanyak dengan jumlah 22 juta orang atau $16.6 \%$. Pada peringkat ketiga, terdapat kelompok mahasiswa dengan jumlah 10.3 juta (7.8\%). Kelompok pelajar berjumlah 8.3 juta orang (6.3\%).

Berbicara mengenai jenis konten Internet yang diakses, sebagaimana dapat diduga, media sosial menjadi konten yang paling dominan diakses. Sebanyak $97.4 \%$ atau
129.2 juta pengguna Internet mengakses media sosial. Konten selanjutnya yang paling banyak diakses adalah hiburan sebanyak $96.8 \%$ atau 128.4 juta orang. Pada peringkat ketiga, konten berita menjadi yang paling banyak diakses dengan persentase tak jauh berbeda dengan konten hiburan, yaitu 96.4\% atau 127.9 juta. Ini disusul dengan konten pendidikan (93.8\% atau 124.4 juta orang), konten komersial (93.1\% atau 123.5 juta orang) dan layanan publik (91.6\% atau 121.5 juta orang).

Mengingat media sosial merupakan konten yang paling banyak diakses, mari kita fokuskan bagaimana data menyangkut perilaku pengguna media sosial di Indonesia. Walaupun sempat diramalkan akan digantikan oleh tren microblogging, namun kenyataannya Facebook masih tetap merajai. Sebanyak 71.6 juta orang, atau $54 \%$ pengguna media sosial di Indonesia mengakses Facebook, diikuti oleh Instagram sebanyak 19.9 juta (15\%), dan YouTube sebanyak 14.5 juta orang $(11 \%)$. Mengagetkan, pengguna Twitter hanya mencapai 7.2 juta orang (5.5\%). Ini artinya, Twitter yang di negara lain menjadi primadona, tidak demikian halnya di Indonesia.

Sebenarnya masih banyak lagi data mengenai perilaku pengguna Internet di Indonesia, yang bisa diekstraksi dari laporan survei APJII 2016. Kendati demikian, dengan melihat sejumlah data basic tersebut, dapat dikatakan bahwa dari segi konten yang diakses, temanya tidak jauh berbeda. Namun demikian, kesenjangan terlihat dari sebaran geografis pengguna Internet yang dominan di pulau Jawa, sebaran usia pengguna Internet yang dominan di kalangan kelompok usia 25 s.d. 44 tahun, sebaran berdasarkan profesi yang didominasi oleh kalangan pekerja/ wiraswasta diikuti oleh Ibu Rumah Tangga (IRT), serta dominasi Facebook sebagai media sosial yang paling banyak diakses oleh pengguna Internet di Indonesia. 
Kenyataan menunjukkan, banyaknya jumlah pengguna Internet di Indonesia, serta tingginya frekuensi mengakses konten informasi dan media sosial, tidak serta-merta menjamin 'kedewasaan' netizen Indonesia dalam menggunakan Internet. Selain kesenjangan yang terjadi, berbagai kasus penyalahgunaan Internet juga marak, mulai dari internet fraud, adiksi atau kecanduan, pelanggaran privasi, bias realitas, hingga yang paling mutakhir adalah meluasnya hoax. Jika ditelisik, sejumlah kasus tersebut bermuara pada satu hal, yaitu rendahnya literasi digital masyarakat Indonesia.

Bertitiktolak dari kenyataan tersebut, sejumlah pihak melakukan berbagai upaya untuk meningkatkan literasi digital di tengah masyarakat. Upaya yang sebenarnya telah dimulai bertahun-tahun silam itu dilakukan dengan menggunakan berbagai pendekatan guna menuntaskan berbagai isu terkait dengan permasalahan digital. Ada yang memakai pendekatan general, yaitu memberikan pembekalan literasi digital secara umum. Ada pula yang menggunakan pendekatan tematik, entah itu membidik konten tertentu seperti "anti-hoax", "internet security", atau berfokus pada cohort tertentu seperti “remaja” dan "anak-anak", atau tertuju pada segmen tertentu seperti "guru", “ibu rumah tangga”. Meningkatkan level literasi publik, atau membuat masyarakat menjadi melek digital memang bukan tugas yang bisa diwujudkan melalui satu dua pendekatan saja. Namun, harus dilakukan melalui berbagai sisi.

Kendati demikian, resikonya, gerakan literasi digital menjadi sporadis dan terkesan 'tanpa' agenda yang jelas. Semua kegiatan terkesan reaktif, dalam arti dilakukan sebagai respons sesaat terhadap situasi-situasi tertentu. Akibatnya, sulit menilai sudah sampai di mana gerakan literasi digital di Indonesia telah berproses. Pun sama sulitnya menilai apakah gerakan literasi digital memang betulbetul efektif mengatasi persoalan. Untuk itu, sebelum bergerak lebih jauh mencari resep, model atau pendekatan yang tepat sasaran sesuai dengan situasi yang dihadapi, perlu dilakukan kajian dan pemetaan terhadap gerakan literasi digital di Indonesia, baik dari segi konsep, isu/tema, konten, sasaran, maupun pendekatan aksinya.

Penelitian jelas membutuhkan sumberdaya yang tidak sedikit. Untuk itu, penelitian dilaksanakan dengan melibatkan kerjasama berbagai prodi/jurusan komunikasi di berbagai kota di Indonesia. Inilah yang merupakan keunggulan riset bersama ini, jika dibandingkan dengan riset-riset sejenis yang kemungkinan pernah dilakukan di negara lain. Kelebihan lain dari penelitian bersama ini adalah menjawab persoalan gerakan literasi digital di Indonesia yang cenderung sporadis, reaktif dan tidak berkelanjutan. Pertanyaan yang diajukan dalam penelitian ini adalah bagaimana peta gerakan literasi digital di Indonesia dilihat dari pelaku, ragam kegiatan, kelompok sasaran dan mitra?

Diakhirpenelitian, potretgerakan literasi digital di Indonesia akan menghasilkan semacam peta atau database/direktori terkait dengan isu literasi digital di Indonesia. Pada tahapan selanjutnya, pemetaan ini akan mampu menjawab positioning Indonesia dalam aktivitas literasi digital yang tengah dan telah berlangsung sekarang, sekaligus memberikan rekomendasi bagi gerakangerakan literasi digital berikutnya, sehingga dapat mengisi agenda yang belum terisi atau belum intensif tergarap dalam peta besar literasi digital Indonesia. Rekomendasi ter-sebut juga bermanfaat untuk menyusun modul standar literasi digital sesuai dengan konteks Indonesia, yang bisa berujung pada pelatihan-pelatihan dan/atau kampanye digital di Indonesia melalui berbagai platform.

Literasi secara harfiah diterjemahkan sebagai kemampuan membaca dan menulis. Dalam perkembangannya, kemampuan membaca dan menulis saja ternyata tidak cukup untuk menjadikan manusia agar mampu berfungsi sepenuhnya dalam sebuah masyarakat. Kemampuan baca tulis hakikatnya merupakan sarana bagi seseorang untuk terlibat dalam aspek kehidupan yang jauh lebih luas, seperti melakukan aktivitas yangberhubungandenganilmupengetahuan, melakukan transaksi ekonomi, terlibat dalam 
kehidupan politik, dan sebagainya. Sesuai dengan konteksnya, maka literasi sebagai 'keaksaraan' berkembang menjadi beragam jenis literasi, seperti literasi politik, literasi finansial, literasi hukum, termasuk literasi media, literasi informasi, dan literasi digital.

Konsep literasi media muncul seiring dengan dominasi media di tengah kehidupan manusia yang mentransfer data dan informasi yang digunakan manusia untuk melaksanakan perikehidupannya seharihari. Potter mencatat, pada awalnya para pakar mendefinisikan media literacy sebagai 'the ability to access and process information from any form of transmission'. Definisi tersebut kemudian didetailkan menjadi “... the ability to access, analyse, evaluate and create messages across a variety of contexts (Livingstone, 2003). Inilah definisi yang menjadi pijakan para pegiat literasi media maupun perencana pendidikan untuk diintegrasikan di dalam kurikulum yang bertujuan menciptakan manusia yang mampu berfungsi dengan baik di Abad Informasi. Pendekatan ini dimaknai sebagai pendekatan 'life skill'.

Namun, pertumbuhan media dan fenomenanya ternyata tidak cukup lagi menyelesaikan permasalahan literasi media. Diperlukan cara pandang baru, yang tidak semata-mata mengerangka literasi media sebagai perkara membangun life skill. Pendekatan life skill memang menyelesaikan masalah-masalah teknis. Namun, kenyataannya, pendekatan ini juga menuntut konsumsi media dalam intensitas tinggi, sehingga sulit dikendalikan dan cenderung sehingga berlebihan. Menurut Potter, saatnya kini mengembangkan media literacy as a set of perspective that we actively use to expose ourselves to the media and interpret the meaning of the messages we encounter. It is multidimensional, and a continuum (Potter, 2014:14).

Karakter literasi media yang disebutsebut Potter sebagai 'multidimensional' dan 'continuum' menjadi sangat penting ketika dunia memasuki abad baru, yaitu new media. Menjawab tantangan Livingstone yang melontarkan pertanyaan retoris-filosofis "What's new for society about the new media?" Flew menyatakan bahwa new media bukanlah semata-mata Internet, World Wide Web, atau lompatan perkembangan teknologi komunikasi dan informasi. Adalah penting untuk memahami new media sebagai pertumbuhan media yang berkaitan dengan proses-proses sosial dan teknologi dalam tiga aspek: (1) digitization dan konvergensi; (2) interaktivitas; dan (3) network dan networking (Flew, 2004:19). Kompleksitas new media membutuhkan adanya kemampuan literasi baru-yang tidak semata-mata mengerangka literasi media sebagai cara untuk mengakses dan menggunakan media. Pada titik inilah konsep literasi digital muncul sebagai tuntutan sekaligus panduan untuk menempatkan diri di dalam peradaban media baru.

Konsep literasi digital dilontarkan oleh Paul Gilster pertama kali pada tahun 1997 dalam buku berjudul Digital Literacy. Gilster mendefinisikannya secara sederhana sebagai 'literacy in the digital age', atau kemampuan untuk memahami dan menggunakan informasi melalui beragam sumber digital (Bowden dalam Lankshear \& Knobel, 2008: 18). Dalam perkembangannya, digital literacy atau tepatnya digital literacies didefinisikan sebagai 'practices of communicating, relating, thinking and 'being' associated with digital media' (Jones \& Hafner, 2012:13). Definisi ini bersumber dari akar konsepsi perkembangan media digital sebagai social phenomenonfenomena sosial, yang membawa berbagai konsekuensi ekonomi, sosial dan politik. Istilah 'practices' dipilih karena konsep ini mencakup segala cara untuk memanfaatkan literasi secara aktif, termasuk aktivitas pemaknaan yang melandasinya.

"Literacy practices are made up of specific activities and at the same time are part of broader social processes... The concept provides the route map for thinking about topics as diverse as the role of agency, and the significance of the body, objects and texts. It clarifies the relations of actions and discourse ... Human life are made up of social practices. That is the reason why we 
emphasize people's lived experiences and everyday relations to technologies ...” (Barton \& Lee, 2013: 30-31).

Dalam dunia virtual dimana internet menjadi media baru yang sangat penting dalam kehidupan sehari-hari, dibutuhkan adanya pemahaman dan agensi penggunanya, sebab teknologi hanyalah alat semata yang tidak menentukan bagaimana kita harus bertindak (Koltay, 2011). Untuk itu dibutuhkan serangkaian pemahaman dan tindakan dengan menerapkan berbagai literasi media baru alias literasi digital.

Arti penting literasi digital tidak hanya dikarenakan tingginya terpaan media saja, melainkan adanya beberapa faktor lainnya. Pertama, peran penting informasi dalam proses demokrasi. Kedua, peran penting partisipasi budaya dan kewarganegaraan. Ketiga, berkembangnya budaya popular membuat anak dan remaja semakin banyak mengakses media digital (Koltay, 2011). Potter menambahkan, peran penting literasi media dalam bentuk baru ini juga didorong oleh tingginya pertumbuhan media yang tidak sebanding dengan kemampuan manusia untuk mengimbanginya. Sebagai gambaran, pertumbuhan media dirinci oleh Potter;

Our culture is saturated with media messages-far more than you may realize. Hollywood releases more than 700 hours feature films each years, which adds to its base of more than 100.00o hours of films they have already released in the previous years. In addition, users of a video platform such as YouTube upload more than 100.000 new hours of video every day (Youtube, 2013). Commercial television stations generate about 48 million hours of video messages every year worldwide, and radio station send out 65.5 million hours of original programming each year. We now have more than 140 million books titles in existence, and another 1.500 new book titles are published through the world each day. Then there is the World Wide Web-or Internet which is so huge that no one knows how big it really is. Google started indexed web pages about a decades ago and has now totaled 13.4 billion pages in the World Wide Web (Kunder, 2013) which has been estimated to be only $1 \%$ of all web pages (Sponder, 2012) (Potter, 2014:5-4).

Potter mengilustrasikan pertumbuhan media di tahun 2014, berdasarkan observasi di tahun 2013. Maka bisa dibayangkan, ketika tulisan ini dibuat, sudah berapa kali lipat pertumbuhan yang terjadi.

Sementara pertumbuhan media baik dari segi konten maupun teknologi dan aplikasi berkembang pesat, tidak demikian halnya dengan kemampuan manusia untuk mencerna, menyeleksi dan memahami pesan-pesan komunikasi. Setidaknya, ini tergambar dari tingkat literasi yang dari tahun ke tahun sangat mencemaskan karena mengalami penurunan kapasitas literasi sebagaimana disimpulkan oleh kajian-kajian yang memetakan tingkat literasi warga, di antaranya "The World's Most Literate Nation (WMLN)" dari Jhon W. Miller, Presiden Central Connecticut State University New Britain (CCSU, 2016) dan Programme for International Student Assessment (PISA) (OECD, 2012).

Dalam konteks media baru yang ditandai oleh konvergensi media dan interaktivitas, literasi tidak hanya terkait dengan mencerna isi media saja, melainkan juga memproduksi teks yang bersifat multimedia dan bahkan teks yang bersifat interaktif dalam konteks hypermedia. Hal ini disebabkan pertumbuhan penggunaan internet yang sangat pesat (Buckingham, 2006). Tantangan media baru bukan hanya bersumber dari sisi teknologinya, atau bentuk pasar/industri yang menyertainya. Pada media digital, terjadi perubahan posisi khalayak dari audiens pasif menjadi audiens yang memiliki keleluasaan untuk mereproduksi teks secara mandiri berkat sejumlah fasilitas yang dimiliki internet. Di satu sisi, keistimewaan ini merupakan affordances-keuntungan. Di sisi lain membawa tekanan tersendiri karena untuk mampu memanfaatkan affordances tersebut, dibutuhkan kemampuan yang tidak sekadar terbatas pada penguasaan akses dan teknologi. 
Affordances senantiasa datang bersama constraints - tekanan-tekanan. Menghadapi teks-teks digital, karena itu, membutuhkan modalitas yang berbeda untuk mampu menghadapi affordances dan constraints, serta menempatkan diri dalam konteks mediasi di tengah-tengah affordances dan constraints tersebut.

Multimodal texts in many print-based media (and even websites) is relatively static and are created by a single author. In Web 2.o spaces, by contrast, multimodal content can be co-created and constantly edited by multiple users. The convergence of writing spaces in new social media presents new opportunities for easy creation, posting, and sharing of multimodal texts. (Barton \& Lee, 2013:30)

Contoh yang ditampilkan dalam kutipan di atas memperlihatkan salah satu dampak perkembangan teknologi dalam digital media, yaitu meningkatkan konten multimodal yang biasanya ditemui dalam teks. Menggabungkan unsur visual, teks, dan audio sekaligus, konten yang dijumpai dalam media digital mengombinasikan beberapa modalitas sekaligus-inilah yang disebut dengan multimodality. As a result, a range of new literacies are needed to cope with the proliferation of images, graphics, video, animation and sound in digital texts (Jones \& Hafner, 2012:50). Oleh karena itu penggunaan istilah literasi sendiri sebenarnya mengandung arti jamak bukan tunggal. Sebab, dengan meningkatkan penggunaan media konvergensi mengandung makna literasi jamak yang mencakup berbagai literasi dari serangkaian bentuk komunikasi dan media kontemporer (Buckingham, 2006). Media digital adalah wujud dari komunikasi dan media kontemporer yang disitir oleh Buckingham.

Sebagai bagian dari literasi media, literasi digital sendiri bukanlah konsep yang benar-benar baru. Selain literasi digital sebenarnya juga terdapat konsep yang disebut dengan literasi komputer yang muncul pada tahun 1980an. Konsep ini dianggap tidak memadai untuk kebutuhan literasi media, sebab hanya membawa makna pada literasi komputer secara teknis atau penguasaan komputer semata. Oleh karena itu, konsep digital literasi kemudian mengemuka karena konsepsinya tidak hanya terkait dengan penguasaan teknis komputer semata melainkan juga pengetahuan dan juga emosi dalam menggunakan media dan perangkat digital termasuk internet (Buckingham 2006). Konsep lain yang juga terkait dengan literasi digital adalah literasi informasi yang membekali khalayak dengan kemampuan untuk mencerna, memahami, menyeleksi, dan mendapatkan kembali (to retrieve) informasi di tengah banjir informasi yang terjadi.

Apapun cara pandangnya, konsep literasi digital tidak berdiri sendiri, tetapi terkait dengan beberapa konsep literasi lainnya. Penelitian ini mengedepankan literasi digital karena menimbang bahwa literasi informasi semata-mata membatasi pada kemampuan memahami dan menyeleksi informasi, literasi komputer atau TIK semata-mata terarah pada penguasaan alat, sedangkan literasi digital yang terfokus pada platform digital menempatkan mediasi sebagai persoalan utama.

'Digital literacies' involve not just being able to 'operate' tools like computers and mobile phones, but also the ability to adapt the affordances and constraints of these tools to particular circumstances ... In other words, while we may seem at times to focus quite heavily on the 'digital' part of digital literacies, that is, to dwell on the affordances and constraints of these new technologies, what we are really interested in is not the tools themselves, but the process of mediation, or, as others called it, mediated action (Scollon, 2001; Wertch, 1993), the process through which people appropriate these tools to accomplish particular social practices. (Jones \& Hofner, 2012:19)

Dengan pemaknaan bahwa literasi digital adalah sebuah konsep yang mengarah pada mediasi antara teknologi dengan khalayak atau user untuk mempraktikkan teknologi digital secara produktif, maka 
gerakan literasi digital pun dirancang dan diselenggarakan di berbagai wilayah. Tujuan dari kegiatan literasi digital pada dasarnya sama, walaupun aktivitasnya bervariasi.

A digitally literate person: (1) Possesses the variety of skills - technical and cognitive - required to find, understand, evaluate, create, and communicate digital infor-mation in a wide variety of formats; (2) Is able to use diverse technologies appropriately and effectively to re-trieve information, interpret results, and judge the quality of that in-formation; (3) Understands the relationship between technology, life-long learning, personal privacy, and stewardship of information; (4) Uses these skills and the appropriate technology to communicate and collaborate with peers, colleagues, family, and on occasion, the gen-eral public; and (5) Uses these skills to actively participate in civic society and contribute to a vibrant, informed, and engaged community. (ALA Digital Literacy Taskforce, 2011)

Dengan tujuan menciptakan manusia digital berikut segala kapasitas/ kompetensinya, menjadi jelas bahwa tugas literasi digital tidaklah mudah-bahkan untuk lembaga dunia sekelas PBB. Walaupun proyek digitalisasi telah dimulai sejak 1980, UNESCO baru menyentuh persoalan literasi digital pada bulan Mei 2007 sebagai tindak lanjut Konferensi Lisbon. Secara resmi, aspek-aspek literasi digital menjadi bagian dari 16 indikator yang dirumuskan oleh Education Council sebagai wujud 'measuring information society'. Aspekaspek literasi digital tersebut adalah ICT skills, civic skills, learning to learn skills, dan participation of adults in lifelong learning, dengan prioritas pada area-area yang terkait dengan pengembangan digital competencetermasuk pengembangan infrastruktur (IITE Policy Brief, 2011). Sebagai catatan, isu literasi baru masuk agenda UNESCO pada tahun 2004, jadi jangan terkejut jika isu literasi digital baru muncul tiga tahun kemudian.

Negara-negara maju seperti Amerika Serikat, Kanada dan Australia merespons
UNESCO Policy Brief mengenai digital literacy setahun kemudian, walaupun pelbagai studi pendahuluan dan aktivitas di ruang pendidikan telah dimulai sejak 2006, di antaranya melalui proyek besar Digital Information Forecast Research (2006-2011) dan Project of Information Literacy yang dimulai sejak 2008 (Head, 2009:2). Negaranegara di Asia seperti China dan Jepang dengan cepat juga menyamai gerak negaranegara maju tersebut dalam mengakuisisi konsep-konsep literasi digital untuk pengembangan SDM. India dan Singapura tidak ketinggalan.

Di belahan Afrika, Afrika Selatan tercatat sebagai negara yang cukup progresif dalam memasukkan literasi digital sebagai bagian dari kurikulum pendidikan formal. Dimulai dari tingkat perguruan tinggi (2012), selanjutnya literasi digital diadopsi menjadi bagian dari kurikulum dasar. Studi tentang literasi digital pada siswa sendiri secara general telah dimulai pada tahun 2010, kemudian berlanjut pada topik-topik yang lebih spesifik semisal pemanfaatan blogging, visual arts melalui media digital, hingga digital story-telling dan music making. Saat kurikulum literasi digital mulai diadopsi pada tahun 2014, Afrika Selatan memiliki persiapan yang cukup matang (Brown \& Mayisela, 2015:3).

Di Indonesia, aroma literasi digital sesungguhnya sudah tercium sejak kurikulum TIK (Teknologi Informasi dan Komunikasi) menjadi bagian dari Kurikulum 2006 atau KTSP. Dengan alasan bahwa pembelajaran TIK dapat diintegrasikan pada mata pelajaran lainnya, maka subjek TIK pun dihilangkan dari Kurikulum 2013, sehingga menimbulkan kontroversi yang cukup panas di kalangan pendidik, baik dari komunitas guru-guru TIK maupun lingkungan sekolah secara general. Terlepas dari pro kontra yang terjadi, kegiatan literasi digital di Indonesia berlangsung terus, termasuk yang berbasis kerelawanan. Di tingkat nasional, Gerakan Relawan TIK (RTIK) dimotori oleh Kemkominfo dan berhasil menjaring simpatisan di berbagai propinsi. Perguruan tinggi pun aktif bergerak, khususnya prodi 
ilmu komunikasi di berbagai wilayah yang sebelumnya pernah terlibat dalam gerakan literasi media. Di luar itu, komunitaskomunitas dan LSM juga aktif berkiprah, terutama setelah isu hoax-anti hoax bergema di tingkat nasional. Pada titik ini, kebutuhan literasi digital tampaknya berhasil menyatukan berbagai pihak dengan latar belakang yang bervariasi untuk bersamasama mengangkat isu ini.

\section{METODE}

Penelitian bersama ini dilakukan dengan metode Desk Study dan Case Study. Metode Desk Study dilaksanakan melalui studi literatur mengenai gerakan literasi digital di Indonesia berdasarkan dokumendokumen terkait, seperti laporan kegiatan, berita media massa, arsip, dan sebagainya. Sementara Case Study untuk mengeksplorasi keunikan maupun tantangan khas di setiap kota dilaksanakan melalui FGD atau wawancara mendalam terhadap para pemangku kepentingan literasi digital.

Sebagai penelitian yang melibatkan banyak sumberdaya, maka salah satu tantangan yang dihadapi adalah mengelola kelompok besar yang masing-masing memiliki berbagai kesibukan tersendiri. Untuk memudahkan pengelolaan tim peneliti, sekaligus menyelaraskannya dengan tujuan penelitian, maka dalam prosesnya penelitian ini dibagi-bagi menjadi sejumlah tahapan yang terangkum dalam alur seperti tergambar dalam Bagan 1.

Alurpada baganı memperlihatkan empat tahapan penelitian bersama. Tahap Nol (Tier o) dimulai dari penelitian individu peneliti di masing-masing prodi/perguruan tinggi yang sifatnya adalah pilihan. Sedangkan Tahap Pertama (Tier Pertama) adalah penelitian di level prodi/perguruan tinggi yang wajib dilakukan oleh peneliti atau tim peneliti di masing-masing insitusi untuk memetakan gerakan literasi digital di perguruan tinggi masing-masing dan atau insitusi lainnya sesuai kesepakatan dengan perguruan tinggi lain di kota yang sama, jika ada. Hasil gabungan dari laporan penelitian di masing- masing institusi pada level kota merupakan tahapan selanjutnya (Tier Kedua), yang lantas dijadikan satu sebagai hasil penelitian bersama yang menggambarkan gerakan literasi digital di 9 kota di Indonesia (Tier Ketiga). Laporan penelitian ini adalah output dari Tier Ketiga, yaitu hasil penelitian bersama yang memetakan aktivitas literasi digital di 9 kota (data nasional).

Penelitian ini melibatkan 56 peneliti yang berasal dari 28 prodi dari 26 perguruan tinggi di 9 kota di Indonesia (Yogyakarta, Salatiga, Semarang, Surakarta, Malang, Bandung, Banjarmasin, Bali dan Jakarta) sebagaimana yang terlihat dalam tabel 1.

Dari tabel 1 terlihat bahwa peneliti masih didominasi kota-kota di pulau Jawa, sedangkan yang berasal dari luar Jawa hanyalah Bali dan Banjarmasin. Menimbang keterlibatan institusi, maka Kota Yogyakarta adalah yang terbanyak-diwakili 10 perguruan tinggi. Demikian pula dengan jumlah penelitinya, sebagaimana terlihat dalam Grafik 1 dan 2 berikut ini. Para peneliti di sini adalah dosen, alumni, dan mahasiswa. Gambaran selengkapnya dapat dilihat dalam Grafik 1 dan 2 berikut ini.

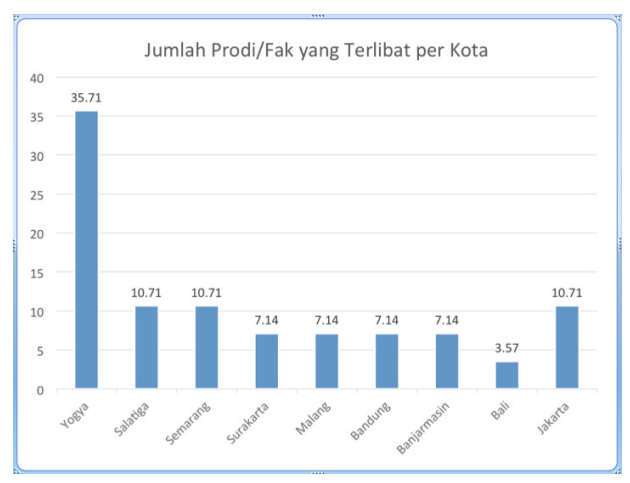

Grafik 1. Jumlah Prodi/Fak Per Kota

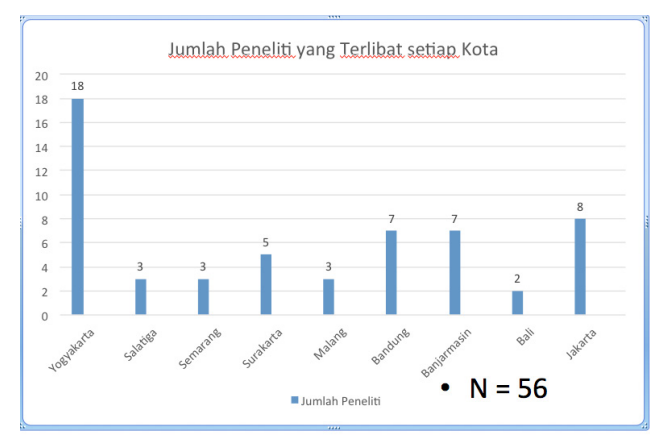

Grafik 2. Jumlah Peneliti Per Kota 
Novi Kurnia dan Santi Indra Astuti, Peta Gerakan Literasi Digital di Indonesia: Studi tentang Pelaku, ...

$\underline{\text { Penelitian Individu }} \rightarrow \underline{\text { Penelitian Perguruan Tinggi }} \rightarrow \underline{\text { Penelitian Kota }} \rightarrow \underline{\text { Penelitian Bersama }}$ TIER 0 TIER 1 TIER 2 (mikro) TIER 3 (makro)

\section{Bagan 1. Alur Penelitian}

Tabel 1. Komposisi Tim Peneliti JAPELIDI

\begin{tabular}{|c|c|c|c|}
\hline No. & Kota & Prodi/Fakultas \& Perguruan Tinggi & $\begin{array}{l}\text { Jumlah } \\
\text { peneliti }\end{array}$ \\
\hline \multirow[t]{10}{*}{$\mathbf{1}$} & \multirow[t]{10}{*}{ Yogyakarta } & 1. Paskasarja (S2) Ilmu Komunikasi UGM (koordinator) & 5 \\
\hline & & 2. Prodi Komunikasi UNY & 2 \\
\hline & & 3. Prodi Ilmu Komunikasi UPN & 1 \\
\hline & & 4. Prodi Ilmu Komunikasi UMY & 1 \\
\hline & & 5. Prodi Ilmu Komunikasi STPMD “APMD” & 1 \\
\hline & & $\begin{array}{l}\text { 6. Prodi Ilmu Komunikasi Universitas Atmajaya } \\
\text { Yogyakarta }\end{array}$ & 1 \\
\hline & & 7. STMM “MMTC" & 2 \\
\hline & & 8. Prodi Ilmu Komunikasi UIN & 2 \\
\hline & & 9. Prodi Ilmu Komunikasi Universitas Respati Yogyakarta & 1 \\
\hline & & 10. Prodi Komunikasi Universitas Islam Indonesia & 2 \\
\hline \multirow[t]{3}{*}{2} & \multirow[t]{3}{*}{ Salatiga } & $\begin{array}{l}\text { 1. Prodi Public Relations, Universitas Kristen Satya } \\
\text { Wacana }\end{array}$ & 1 \\
\hline & & 2. Fakultas Psikologi, Universitas Kristen Satya Wacana & 1 \\
\hline & & $\begin{array}{l}\text { 3. Prodi DIII Teknologi Komunikasi, Universitas Kristen } \\
\text { Satya Wacana }\end{array}$ & 2 \\
\hline \multirow[t]{3}{*}{3} & \multirow[t]{3}{*}{ Semarang } & 1. Sekolah Tinggi Ilmu Komunikasi (STIKOM) Semarang & 1 \\
\hline & & \begin{tabular}{|l} 
2. Prodi Penyiaran Fakultas Ilmu Komputer Universitas \\
Dian Nuswantoro \\
\end{tabular} & 1 \\
\hline & & $\begin{array}{l}\text { 3. Prodi Ilmu Komunikasi Fakultas Bahasa dan Ilmu } \\
\text { Komunikasi Universitas Islam Sultan Agung } \\
\end{array}$ & 1 \\
\hline \multirow[t]{2}{*}{4} & \multirow[t]{2}{*}{ Surakarta } & 1. Ilmu Komunikasi Universitas Negeri Sebelas Maret & 2 \\
\hline & & $\begin{array}{l}\text { 2.Prodi Ilmu Komunikasi Universitas Muhammadiyah } \\
\text { Surakarta }\end{array}$ & 3 \\
\hline \multirow[t]{2}{*}{5} & \multirow[t]{2}{*}{ Malang Raya } & \begin{tabular}{|l|} 
1. Prodi Ilmu Komunikasi FISIP, Universitas \\
Muhammadiyah Malang
\end{tabular} & 2 \\
\hline & & $\begin{array}{l}\text { 2. Prodi Komunikasi, FISIP, Universitas Tribuana } \\
\text { Tunggadewi Malang }\end{array}$ & 1 \\
\hline \multirow[t]{2}{*}{6} & \multirow[t]{2}{*}{ Bandung } & Prodi Ilmu Jurnalistik Universitas Islam Bandung & 3 \\
\hline & & Program Studi Ilmu Komunikasi Telkom University & 3 \\
\hline 7 & Banjarmasin & $\begin{array}{l}\text { Prodi S1 Ilmu Komunikasi FISIP Universitas Lambung } \\
\text { Mangkurat (UNLAM) }\end{array}$ & 7 \\
\hline 8 & Bali & Prodi Ilmu Komunikasi, FISIP Udayana & 2 \\
\hline \multirow[t]{3}{*}{9} & \multirow[t]{3}{*}{ Jakarta } & Prodi Ilmu Komunikasi Universitas Al Azhar Indonesia & 2 \\
\hline & & Prodi Ilmu Komunikasi Universitas Paramadina & 3 \\
\hline & & $\begin{array}{l}\text { Fakultas Ilmu Komunikasi Universitas Prof Dr Moestopo } \\
\text { (Beragama) }\end{array}$ & 3 \\
\hline & 9 Kota & $\begin{array}{l}28 \text { Prodi/Fakultas } \\
26 \text { Perguruan Tinggi }\end{array}$ & $\begin{array}{c}56 \\
\text { Peneliti } \\
\end{array}$ \\
\hline
\end{tabular}


Dari Grafik 1 terlihat bahwa jumlah prodi terbanyak di peringkat kedua ada di Salatiga, Semarang, dan Jakarta. Kota Surakarta, Malang, Bandung dan Banjarmasin berada di peringkat ke-3. Adapun Bali menjadi wilayah dengan jumlah peneliti paling sedikit karena hanya diwakili oleh 1 prodi dari 1 universitas. Sementara itu, kalau dilihat dari jumlah peneliti, Yogyakarta memiliki jumlah peneliti yang paling banyak (18 peneliti) sedangkan Bali yang paling sedikit (2 peneliti). Dengan begitu, jumlah peneliti berbanding lurus dengan jumlah perguruan tinggi sebagaimana bisa dilihat dalam grafik 2.

Sejumlah 56 peneliti yang tergabung dalam Japelidi memetakan tidak kurang dari 342 kegiatan literasi digital di kota masingmasing, baik yang dilakukan di perguruan tinggi tempatnya bekerja, maupun oleh berbagai institusi lain seperti pemerintah, komunitas, media, korporasi, dan lainnya. Adapun persebaran kegiatan literasi digital yang tercatat dalam penelitian bisa dilihat pada grafik berikut.

\section{Grafik 3. Presentase Kegiatan Literasi Digital Per Kota}

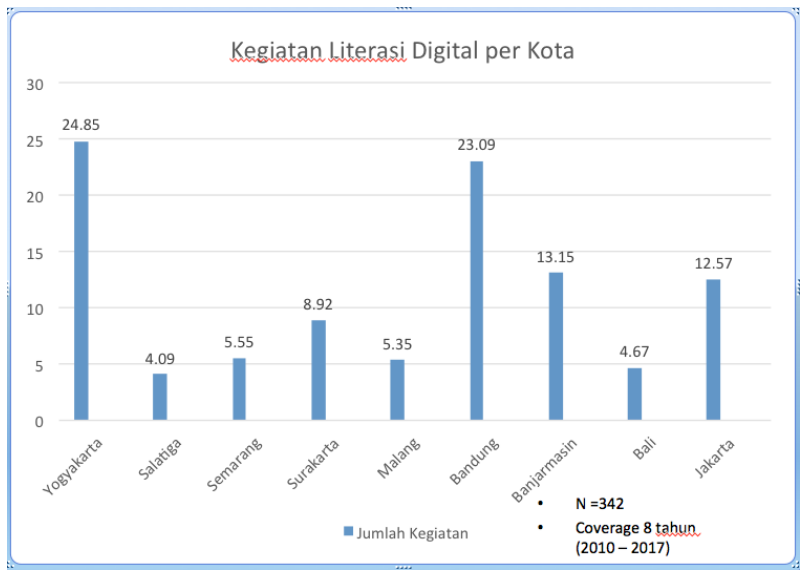

Yang dimaksud dengan kegiatan literasi digital adalah segala aktivitas yang terkait dengan penelitian dan pengabdian kepada masyarakat atau transfer of knowledge bertemakan literasi digital. Istilahnya sendiri tidak selalu literasi digital, tetapi bermacammacam tergantung dari latar belakang penyelenggara, pemahaman penyelenggara, maupun pendekatan dan tujuan kegiatan. Tim menyepakati bahwa sepanjang tujuan akhirnya merefleksikan visi dan misi literasi digital, maka apapun nama dan kemasan kegiatannya tetap disertakan dalam pemetaan ini.

Setelah temuan setiap kota diakumulasikan, terkumpul tak kurang dari 342 kegiatan literasi digital di 9 kota, dengan komposisi terbesar adalah Yogyakarta $(24,85 \%)$, diikuti oleh Bandung (23,09\%) dan Banjarmasin di posisi ketiga (13,15\%). Yang paling sedikit adalah Salatiga (4.09\%). Kegiatan literasi digital yang dicover berlangsung dari tahun 2010 hingga 2017 per Juni 2017. Rentang waktunya mencapai 8 (delapan) tahun.

Pengumpulan 342 kegiatan literasi digital ini berdasarkan metode snowballing yang bergulir dari satu kegiatan literasi digital ke kegiatan lainnya yang dilakukan oleh para pegiat literasi digital di kota masingmasing pada kurun waktu April hingga awal September 2017. Proses snowballing dimulai dari masing-masing peneliti yang kemudian dibawa ke level perguruan tinggi untuk kemudian disinkronkan dengan perguruan tinggi lain di kota yang sama. Gabungan dari data yang didapatkan dari 9 kota kemudian dikumpulkan menjadi satu untuk menunjukkan data "Indonesia". Data ini bukanlah sampel yang dapat digeneralisasikan secara statistik. Namun setidaknya, geliat literasi digital di 9 kota ini dapat memberikan gambaran mengenai upaya yang telah dilakukan berbagai pihak di Indonesia untuk mengatasi permasalahan yang bermuara pada literasi digital.

\section{HASIL DAN PEMBAHASAN}

Bagian ini menjelaskan temuan penelitian dan pembahasannya ditinjau dari aspek pelaku, ragam kegiatan, kelompok sasaran, dan mitra. Pembahasan secara mendetail dilakukan berdasarkan urutan di atas, dimulai dari temuan menyangkut aktor atau pelaku kegiatan literasi digital. 


\section{Pelaku Kegiatan Literasi Digital}

Dilihat dari pelaku gerakan literasi media di 9 kota Indonesia, perguruan tinggi $(56,14 \%)$ adalah pelaku utama yang disusul dengan pemerintah (14,34\%), komunitas $(13,52 \%)$, lembaga swadaya masyarakat $(5,32 \%)$, sekolah dan korporasi masingmasing sebesar 3,68\%. Pelaku lainnya adalah asosiasi profesi dan ormas sebesar 2,86\%, plus media (o,4\%). Komposisi lengkapnya dapat dilihat pada Grafik 4.

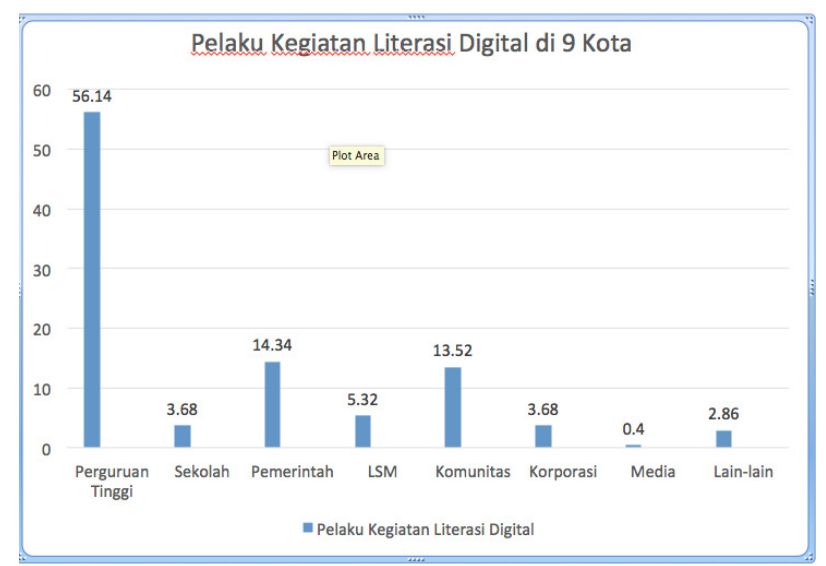

Grafik 4. Presentase Pelaku Kegiatan Literasi Digital di 9 Kota

Tingginya frekuensi perguruan tinggi sebagai pelaku beragam kegiatan literasi digital antara lain disebabkan adanya tuntutan melaksanakan Tri Darma Perguruan Tinggi, khususnya pada program pengabdian masyarakat. Berkaca pada analisis situasi yang ada, maka para pegiat literasi digital kalangan kampus ini pun menyertakan literasi digital sebagai bagian program pengabdian masyarakat. Maraknya program semacam ini akhirnya memosisikan perguruan tinggi sebagai motor gerakan literasi digital di kotanya masing-masing.

Berdasarkan kategorisasi pelakunya, maka terlihat bahwa pelaku literasi digital dari kalangan kampus paling banyak ditemukan di Yogyakarta (57 kegiatan). Sedangkan pelaku sekolah (6 kegiatan) dan lembaga swadaya masyarakat (4 kegiatan) paling banyak muncul di Jakarta. Korporasi (6 kegiatan) dan media (1 kegiatan) paling banyak muncul di Bandung. Sementara itu pemerintah paling banyak muncul di Banjarmasin (6 kegiatan). Surakarta memang layak disebut sebagai Kota Komunitas. Kegiatan literasi digital dengan pelaku komunitas paling banyak muncul di Surakarta (5 kegiatan). Data selengkapnya bisa dilihat di Grafik 5 .

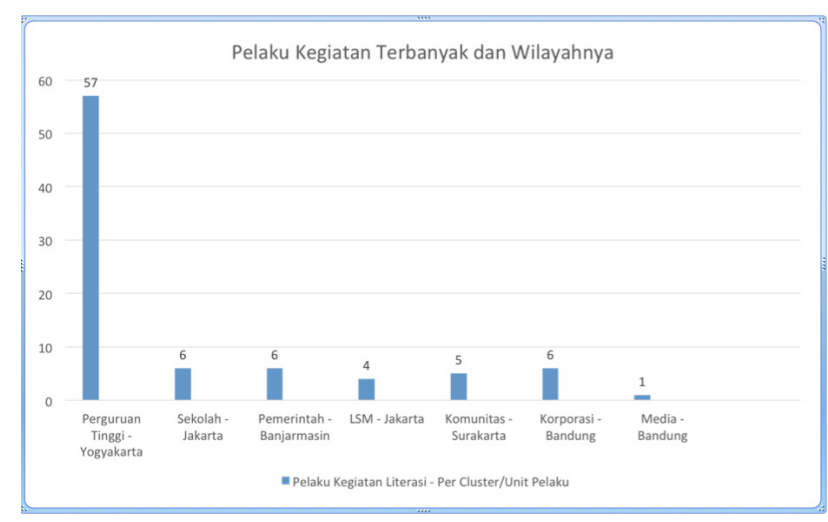

Grafik 5. Kategori Pelaku Kegiatan
Terbanyak dan Wilayahnya

Jika Grafik 5 menjelaskan Frekuensi Pelaku Kegiatan Terbanyak berdasarkan Kategori Pelakunya, maka pada Grafik 6 ditampilkan frekuensi pelaku kegiatan paling dominan di tiap kota. Sebagaimana dapat diduga berdasarkan data umum, maka pada Grafik 6, terlihat bahwa pelaku kegiatan literasi digital paling dominan di sebagian besar kota (Yogyakarta, Salatiga, Semarang, Malang, Bandung, Bali dan Jakarta) adalah perguruan tinggi.

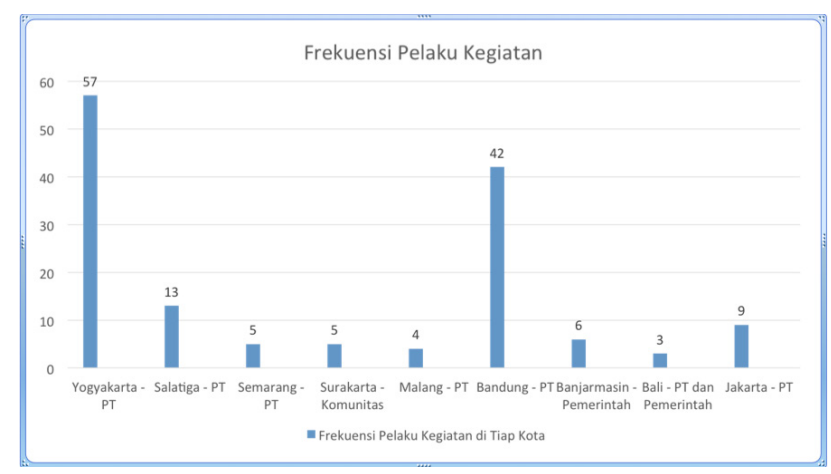

Grafik 6. Frekuensi Pelaku Kegiatan Terbanyak di Setiap Kota

Meskipun begitu, di beberapa wilayah, perguruan tinggi tidak selalu mendominasi kategori aktor atau pelaku kegiatan literasi 
digital. Di Bali, pelaku perguruan tinggi sama banyaknya dengan pelaku pemerintah. Sedangkan di Surakarta, pelaku dominannya bukanlah perguruan tinggi melainkan komunitas. Yang dimaksud dengan pelaku sendiri adalah aktor atau inisiator atau manajer utama dari kegiatan literasi digital, sebagaimana ditemukan dalam laporan desk study. Para pelaku kegiatan literasi digital ini menjadi penanggungjawab formal kegiatan yang dilaksanakan. Apabila pelaku kegiatan lebih dari satu, maka yang menandatangani laporan kegiatan atau penanggungjawab kegiatan otomatis dianggap punya peran paling dominan sehingga dikategorikan sebagai pelaku. Tanpa mengurangi penghargaan kepada kontribusi masing-masing, pihak lain yang kurang dominan sebagai pelaksana kegiatan literasi digital lantas diposisikan sebagai 'mitra'.

\section{Ragam Kegiatan Literasi Digital}

Dilihat dari ragam kegiatan, sosialiasi atau ceramah $(29,64 \%)$ adalah kegiatan literasi digital yang paling sering dilakukan, diikuti oleh workshop ataupelatihan $(20,9 \%)$, seminar atau diskusi $(14,32 \%)$, penelitian $(11,33 \%)$, talkshow $(11,08 \%)$, publikasi $(4,78 \%)$, kampanye dan advokasi (4,28\%), lain-lain (kompetisi dan pendampingan dan pembentukan unit anti hoaks) sebesar 2,01\% dan kurikulum (1,51\%). Data selengkapnya bisa dilihat di Grafik 7 .

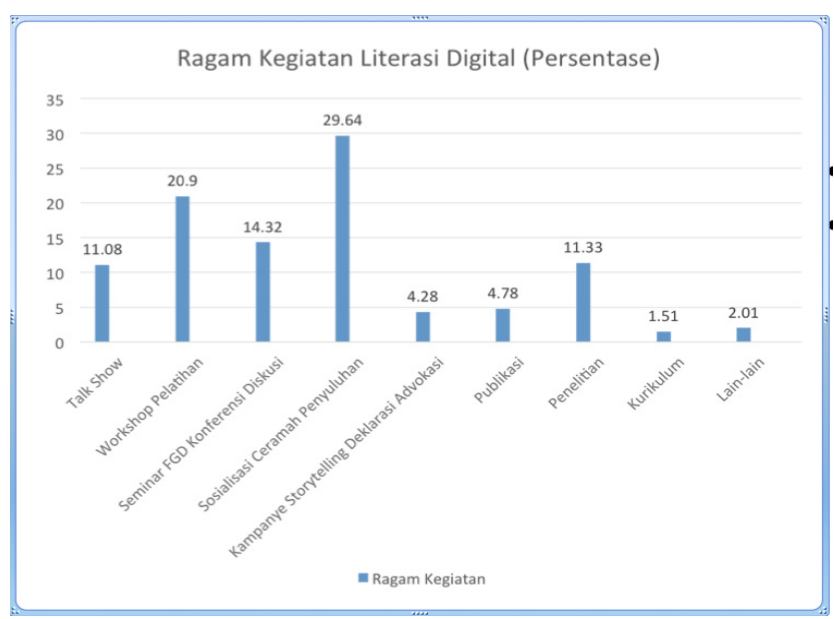

Grafik 7. Presentase Ragam Kegiatan Literasi Digital
Ragam kegiatan literasi digital sangat penting dipetakan karena memperlihatkan dua hal: (1) cara pandang terhadap solusi problematika literasi digital; dan (2) model/ragam kegiatan dominan maupun yang belum banyak dieksplorasi untuk mengedukasi atau mengampanyekan literasi digital. Data pada Grafik 7 memperlihatkan bahwa 'kurikulum' masih menempati urutan terendah sebagai ragam kegiatan literasi digital. Ini disebabkan baru sebagian kecil perguruan tinggi yang menempatkan literasi media atau digital sebagai satu mata kuliah tersendiri. Di antara tim sendiri, tercatat baru beberapa perguruan tinggi yang sudah mempunyai mata kuliah literasi media atau literasi digital, yaitu UGM, Unisba, UNY, Unriyo dan Universitas Paramadina Jakarta.

Selanjutnya, terdapat dua grafik yang akan menjelaskan pemetaan ragam kegiatan literasi digital di 9 kota secara lebih teperinci. Grafik 8 memaparkan frekuensi kegiatan terbanyak berdasarkan kategori kegiatan. Sedangkan Grafik 9 memaparkan temuan ragam kegiatan di masing-masing kota. Jika dilihat dari cluster ragam kegiatan terbanyak pada Grafik 8, nampak bahwa bahwa kegiatan sosialisasi (37 kegiatan) paling banyak ditemukan di Banjarmasin sebagaimana publikasi (7 kegiatan). Sedangkan kegiatan talkshow (21 kegiatan) dan seminar (19 kegiatan) ditemukan paling banyak di Yogyakarta. Sementara itu, workshop (18 kegiatan) dan kurikulum (3 kegiatan) paling banyak ditemukan di Jakarta. Kegiatan penelitian paling banyak ditemukan di Bandung (3 kegiatan), juga ragam kegiatan 'lain-lain' (4 kegiatan). Sedangkan di Malang, kegiatan paling banyak adalah kampanye (5 kegiatan). Yang termasuk dalam kategori 'lain-lain' contohnya adalah lomba bertema literasi digital yaitu blogging dan vlogging, juga pembuatan alat bantu edukasi literasi digital seperti kuartet dan video. 


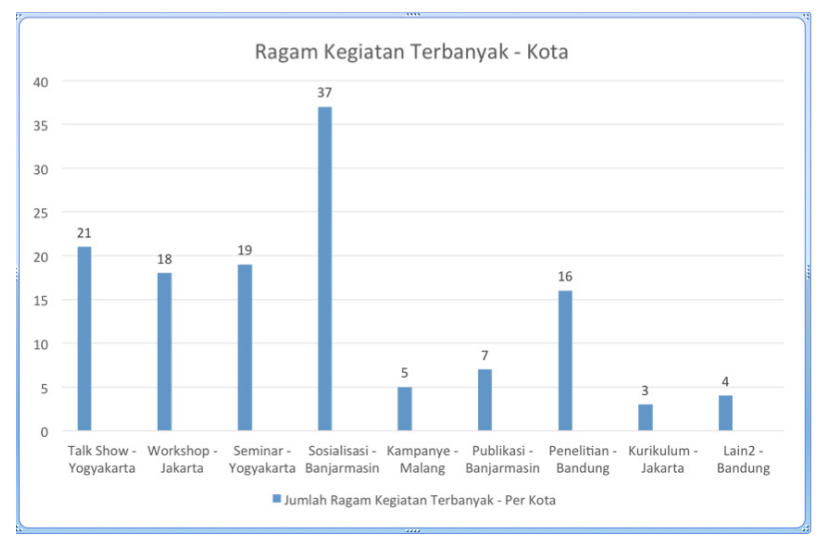

Grafik 8. Frekensi Kegiatan Terbanyak berdasarkan Kategori/Cluster

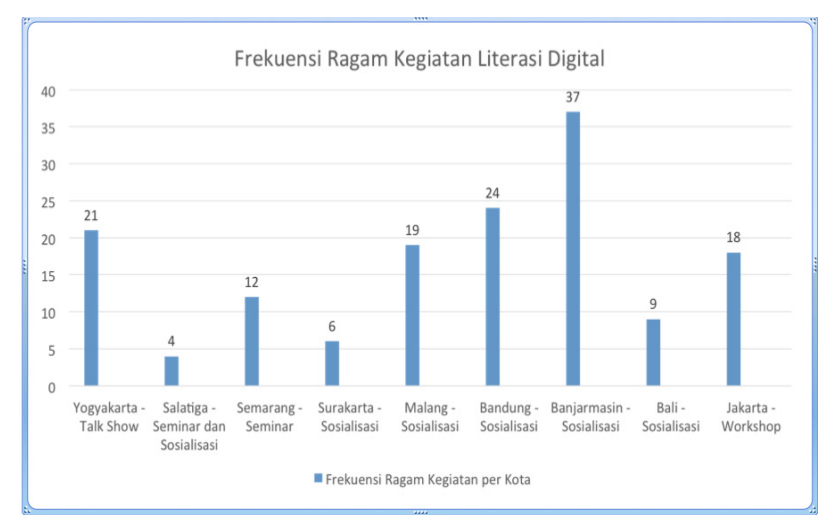

Grafik 9. Frekuensi Kegiatan Literasi Digital Terbanyak per Kota

Grafik 9 memungkinkan komparasi ragam kegiatan literasi digital yang dominan di setiap kota. Talkshow di media terutama radio adalah ragam literasi digital yang paling banyak ditemukan di Yogyakarta karena merupakan program rutin setiap minggu yang dilakukan oleh Prodi Ilmu Komunikasi Universitas Islam Indonesia dengan tema yang kebanyakan mengangkat literasi digital. Sementara itu, kegiatan sosialisasi menjadi program yang dominan di banyak kota: Salatiga, Surakarta, Malang, Bandung, Banjarmasin dan Bali. Khusus untuk Salatiga, program sosialisasi jumlahnya sama dengan program seminar. Sedangkan di Semarang, program seminar tergolong dominan jika dibandingkan program lain.

Banyak hal dapat dianalisis lebih jauh dari data-data ini. Namun yang jelas, ragam kegiatan literasi digital masih didominasi oleh bentuk kegiatan sosialisasi/ceramah/kuliah umum. Dari sisi penyelenggara kegiatan, pilihan sosialisasi sebagai ragam kegiatan yang dominan dapat dimaklumi karena tergolong tidak terlalu rumit persiapannya, durasinya tidak panjang, namun bisa menjangkau banyak orang. Kekurangannya, model sosialisasi atau ceramah cenderung bersifatsatuarah. Diskusitidakterjadi, namun sebatas pada tanya jawab di mana kendali dipegang sepenuhnya oleh moderator atau narasumber, sehingga eksplorasi terhadap hal-hal yang belum jelas pun dikerangka bukan berdasarkan kepentingan user atau peserta ceramah.

Semakin rumit sebuah ragam kegiatan, semakin sedikit disentuh atau dijadikan pilihan untuk menyelenggarakan aktivitas literasi digital. Itu sebabnya kegiatan seperti 'kurikulum' tercatat sebagai aktivitas yang paling minim disentuh. Kegiatan kurikulum memiliki dua varian: pertama, menyertakan mata kuliah literasi media ke dalam kurikulum perguruan tinggi dan/ atau kedua, melakukan pendampingan pada sekolah sasaran guna memasukkan unsurunsur literasi digital ke dalam kurikulum masing-masing. Kedua pilihan sama-sama menantang, butuh kebijakan di tingkat pimpinan, serta membutuhkan persiapan panjang. Karena itu menjadi ragam kegiatan yang paling sedikit dilaksanakan dalam kegiatan literasi digital di 9 kota.

\section{Kelompok Sasaran Kegiatan Literasi Digital}

Mencermati siapa saja kelompok sasaran literasi digital, sangat penting untuk mengevaluasi arah kegiatan literasi digital yang telah berlangsung di Indonesia selama ini. Setidaknya, dengan mencermati kelompok sasaran, dapat diketahui siapa yang selama ini telah terjangkau, dan siapa yang paling sedikit tersentuh oleh literasi digital. Temuan pemetaan memperlihatkan bahwa dilihat dari kelompok sasaran, remaja dan pelajar (29,55\%) merupakan sasaran utama kegiatan literasi digital di 9 kota di Indonesia. Hal ini dikarenakan kaum muda dianggap sebagai kelompok yang paling rentan dan dianggap paling banyak mendapatkan pengaruh buruk dari media digital. Atau sebaliknya, mereka dianggap 
sebagai agen perubahan yang diharapkan bisa turut ambil bagian dalam mengatasi berbagai persoalan masyarakat digital.

Selain siswa/pelajar/remaja, kelompok sasaran kegiatan literasi digital adalah mahasiswa $(18,5 \%)$, masyarakat umum $(15,22 \%)$, orangtua $(12,23 \%)$, guru dan dosen $(10,14 \%)$. Sisanya menarget pihak-pihak seperti ormas, LSM, pemerintah, dan media, dengan porsi sebesar $6,86 \%$. Di urutan terbawah terletak peneliti sebagai target sasaran kegiatan literasi digital (o,29\%). Jenis kegiatannya adalah pembekalan bagi peneliti untuk publikasi ilmiah secara online. Dengan kata, lain, sudah mengarah pada kebutuhan yang sangat spesifik. Untuk target sasaran kegiatan literasi digital dapat disimak selengkapnya dalam Grafik 10.

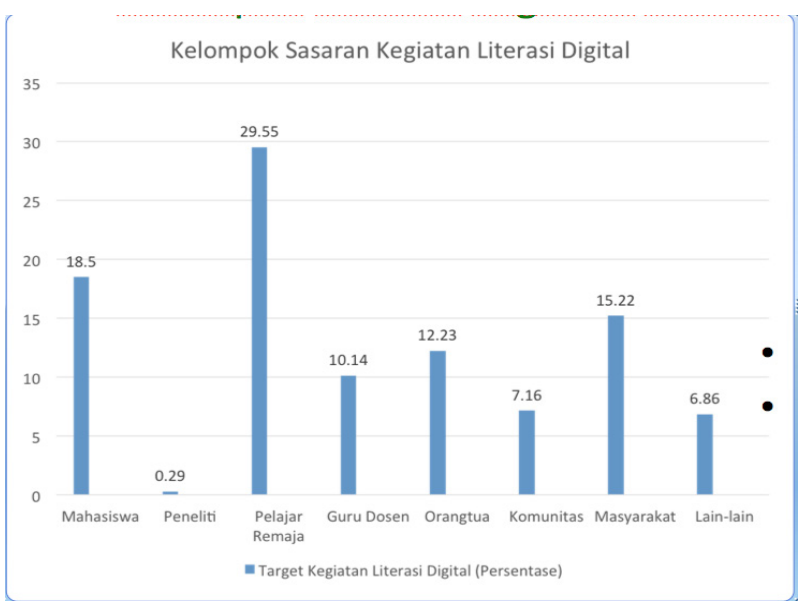

Grafik 1o. Kelompok Sasaran Kegiatan Literasi Digital

Sementara itu, jika dilihat dari clusternya, kategori pelajar dan remaja termasuk kelompok lainnya sebagai target sasaran kegiatan literasi digital paling tinggi frekuensinya di Bandung. Kategori peneliti, komunitas dan masyarakat umum sebagai target sasaran paling banyak dijumpai di Yogyakarta. Sementaraguru/dosen/kalangan pendidik serta orangtua sebagai kelompok sasaran paling banyak ditemukan di Jakarta bila dibandingkan kota lainnya. Untuk kelompok mahasiswa sebagai target sasaran sangat menonjol di beragam kegiatan literasi digital di Malang. Data selengkapnya dapat dilihat pada Grafik 11 yang disandingkan dengan Grafik 12.

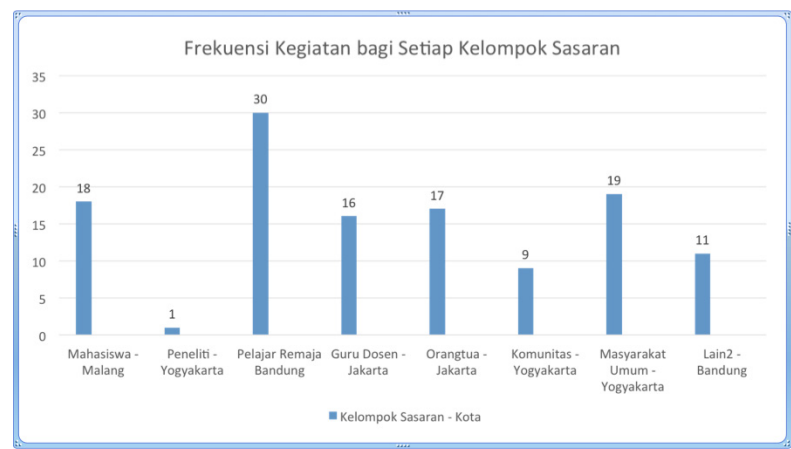

Grafik 11. Frekuensi Kegiatan Setiap Kelompok Sasaran

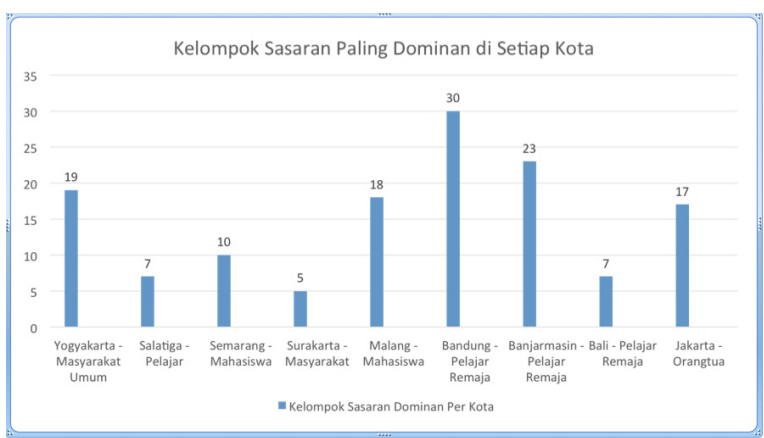

Grafik 12. Kelompok Sasaran Paling Dominan di Tiap Kota

Grafik 12 mengomparasikan target sasaran kegiatan literasi digital terbanyak di setiap kota yang terlibat dalam pemetaan ini. Tercatat di Yogyakarta target sasaran paling banyak adalah masyarakat umum (19 kegiatan), demikian pula dengan di Surakarta (5 kegiatan). Kelompok remaja/ pelajar menjadi target sasaran terbanyak dalam kegiatan literasi digital di empat kota, Bandung (30 kegiatan), Banjarmasin (23 kegiatan), Bali dan Salatiga masingmasing 7 kegiatan. Kegiatan literasi digital di Semarang paling banyak berfokus pada mahasiswa (10 kegiatan). Sementara di Jakarta, target sasaran terbanyak adalah orangtua (17 kegiatan).

Mencerdaskan sebuah masyarakat tidak bisa dilakukan sendirian. Kegiatan literasi digital perlu bermitra dengan banyak pihak untuk mencapai visi-misinya. Siapa sajakah mitra kegiatan literasi digital yang digandeng oleh para pegiat literasi digital di 9 kota, datanya akan dipaparkan dalam bagian terakhir dari temuan pemetan Japelidi. 


\section{Mitra Kegiatan}

Salah satu kunci sukses berkegiatan di era Informasi adalah mengadopsi prinsipprinsip atau value dari teknologi digital itu sendiri. Manusia dikatakan memenuhi prinsip 'digital literate' jika sudah mampu, salah satunya, 'Uses these skills and the appropriate technology to communicate and collaborate with peers, colleagues, family, and on occasion, the general public' (ALA Digital Literacy Taskforce, 2011). Dengan demikian 'komunikasi' dan 'kolaborasi' menjadi kata kunci bagi literasi digital. Dan itu sebabnya mengapa bermitra dan berjejaring menjadi sangat penting. Bagaimanakah selanjutnya para pegiat literasi media mengerangka kegiatannya? Apakah telah menerapkan prinsip-prinsip kolaborasi, bermitra dan berjejaring? Dengan siapa saja mereka telah menjalin kemitraan? Grafik 13 berikut ini memperlihatkan jawaban atas pertanyaan tersebut.

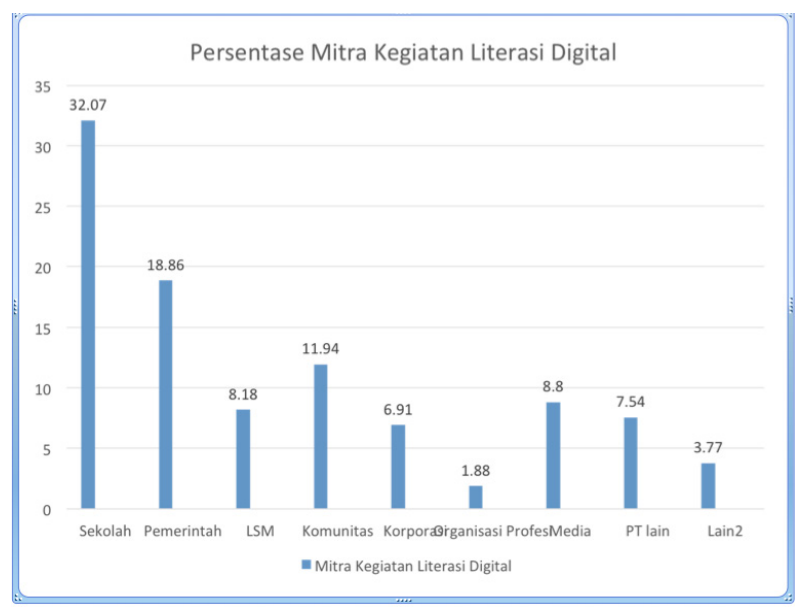

\section{Grafik 13. Komposisi Mitra Kegiatan Literasi Digital}

Mitra kegiatan didefinisikan sebagai pihak-pihak yang turut berkontribusi dalam penyelenggaraan kegiatan, namun tidak bertanggungjawab penuh karena tanggungjawab utama berada di tangan penyelenggara. Keberadaan mitra ditandai dengan kontribusi yang mereka berikan baik dalam bentuk fisik/material seperti sumbangan donasi, penyediaan ruangan, konsumsi, dan lainlain, ataupun berbentuk nonfisik seperti bantuan perijinan, rekomendasi kegiatan, publikasi, dan sebagainya. Dengan N sebesar 159, maka bisa disimpulkan bahwa kegiatan literasi digital yang bermitra sebanyak 46.5\%. Artinya, $53.5 \%$ sisanya adalah kegiatan yang diselenggarakan sendiri tanpa mitra.

Mitra terbanyak dalam melakukan kegiatan literasi digital adalah sekolah (32.07\%), pemerintah $(18,86 \%)$, komunitas $(11,94 \%)$, media $(8,8 \%)$, LSM $(8,18 \%)$, perguruan tinggi lain $(7,54 \%)$, korporasi $(6,91 \%)$, lain-lain (bimbingan belajar, organisasi massa) sebesar 3,77\% dan korporasi dan organisasi profesi (1.88\%). Sekolah menjadi mitra yang paling banyak diajak melakukan gerakan literasi digital karena kelompok sasaran yang paling dominan adalah remaja dan pelajar.

Selanjutnya, pada Grafik 14 dan 15 akan ditampilkan data mengenai mitra dengan frekuensi kegiatan terbanyak berdasarkan kategori mitra, dan komparasi mitra yang paling dominan di setiap kota yang terlibat dalam pemetaan ini.

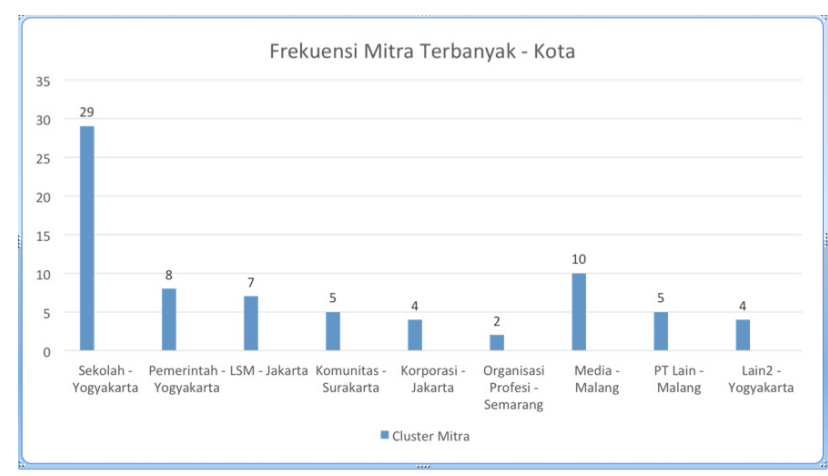

Grafik 14. Frekuensi Terbanyak untuk Setiap Kategori Mitra

Sebagaimana terlihat pada Grafik 14, kegiatan literasi digital yang bermitra dengan sekolah, pemerintah dan lain-lain paling banyak frekuensinya ditemukan di Yogyakarta. Kegiatan yang bermitra dengan sekolah mencapai 29 kegiatan, sementara dengan pemerintah mencapai 8 kegiatan. Demikianlah prestasi Yogyakarta. Kegiatan literasi digital yang bermitra dengan LSM (7 kegiatan) dan Korporasi (4 kegiatan) ditemukan paling banyak frekuensinya di Jakarta. Sebagai kota Komunitas, wajar jika Surakarta paling banyak frekuensi 
kegiatannya yang bermitra dengan komunitas (5 kegiatan). Kegiatan literasi digital yang bermitra dengan media juaranya adalah Malang (1o kegiatan), demikian pula dengan bermitra bersama perguruan tinggi lainnya (5 kegiatan).

Komparasi mitra terbanyak di setiap kota dapat dilihat pada Grafik 15 berikut ini.

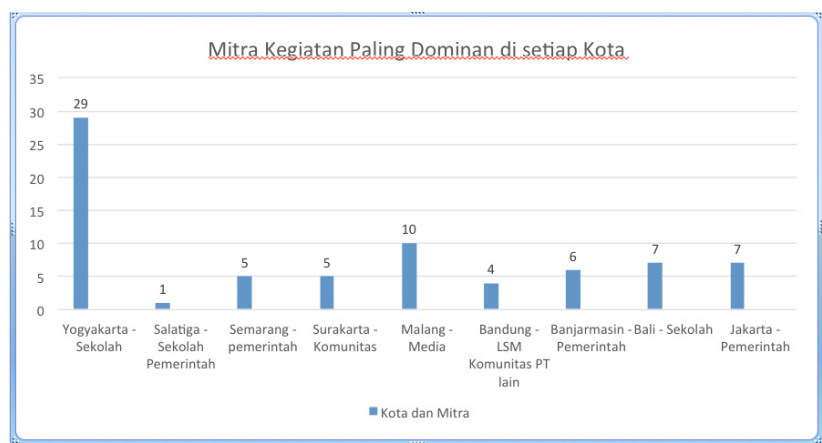

Grafik 15. Mitra Kegiatan Literasi Digital Paling Dominan per Kota

Sesuai dengan data grafik sebelumnya, maka Yogyakarta didominasi oleh mitra sekolah, demikian pula halnya dengan Bali. Semarang, Jakarta dan Banjarmasin memiliki kemitraan yang menonjol dengan pemerintah. Surakarta dikuasai oleh komunitas, Malang menjalin kemitraan terbanyak dengan media, sementara Bandung dan Salatiga bervariasi. Untuk Bandung, kemitraan terbanyak dijalin dengan LSM, Komunitas dan perguruan tinggi lain. Salatiga didominasi oleh kemitraan bersama sekolah dan pemerintah.

Terdapat beragam alasan dan pertimbangan untuk menjalin kemitraan dalam melaksanakan kegiatan literasi digital. Satu hal yang menarik, pemetaan memperlihatkan ragam mitra kegiatan literasi digital yang tidak semata-mata bersandar pada sekolah. Banyak pihak lain juga telah dilibatkan. Ini bermakna, banyak pihak yang sama-sama menganggap literasi digital adalah isunya juga, bukan semata-mata permasalahan inisiator kegiatan. Namun, seperti telah diungkapkan sebelumnya, lebih dari 50\% kegiatan literasi digital dilangsungkan tanpa mitra. Tidak masalah karena tidak ada kewajiban untuk bermitra, namun dari perspektif literasi digital yang menekankan pentingnya kolaborasi, keberadaan mitra dan jejaring mesti diupayakan.

Lagipula, visi misi literasi digital untuk membentuk atau menciptakan generasi yang digital literate itu tidak mudah. It takes a village to raise a child, tutur Hillary Clinton (1996) pada saat menjadi Ibu Negara AS. Dengan kompleksitas literasi digital, it takes more than a village to raise a digital literate kid.

\section{SIMPULAN}

Pemetaan kegiatan literasi digital di 9 kota di Indonesia menghasilkan beberapa kesimpulan. Pertama, pelaku kegiatan lebih banyak didominasi oleh perguruan tinggi. Kedua, ragam kegiatan masih lebih banyak berbentuk sosialisasi/ceramah satu arah. Ketiga, target sasaran kegiatan literasi digital sebagian besar membidik kaum remaja/ pelajar. Keempat, mitra terbanyak berasal dari kalangan sekolah.

Kesimpulan umum ini sedikit berbeda di setiap kota. Terkait dengan empat komponen utama literasi digital yakni pelaku, ragam kegiatan, kelompok sasaran, dan mitra, masing-masing kota memiliki temuan yang khas.

Pertama, di Yogyakarta ditemukan pelaku dominan kegiatan literasi digital adalah PT, dengan ragam talk show, menarget sasaran masyarakat umum dan pelajar, serta bermitra dengan sekolah.

Kedua, di Salatiga, pelaku dominan kegiatan literasi digital adalah perguruan tinggi, dengan ragam sosialisasi dan ceramah, menarget sasaran remaja dengan mitra sekolah dan pemerintah.

Ketiga, di Semarang, pelaku dominan adalah perguruan tinggi, dengan ragam seminar, menarget mahasiswa dengan mitra pemerintah.

Keempat, di Surakarta pelaku dominan adalah komunitas, dengan ragam sosialisasi, menarget masyarakat umum, dengan kemitraan bersama sesama komunitas.

Kelima, di Malang, pelaku dominan adalah perguruan tinggi, dengan ragam 
sosialisasi, menarget mahasiswa, dengan kemitraan media.

Keenam, di Bandung, pelaku kegiatan dominan adalah perguruan tinggi, dengan ragam sosialisasi, menarget pelajar/remaja, bermitra dengan LSM, komunitas, dan PT lain.

Ketujuh, di Banjarmasin, pelaku dominan adalah pemerintah, dengan ragam sosialisasi, menarget pelajar/remaja, bermitra dengan SKPD/instansi pemerintah lainnya.

Kedelapan, di Bali, pelaku dominan kegiatan literasi digital adalah perguruan tinggi dan pemerintah, dengan ragam kegiatan sosialisasi, menarget pelajar/remaja, bermitra dengan sekolah.

Kesembilan, Jakarta, pelaku dominan aktivitas literasi digital adalah Universitas, dengan ragam kegiatan workshop, menarget orangtua, dan paling banyak bermitra dengan pemerintah.

Selain keunikan masing-masing kota, penelitian yang dilakukan oleh JAPELIDI ini juga melihat bahwa gerakan literasi digital di Indonesia cenderung bersifat sukarela, insidental, sporadis dan belum ada sinergi antar pelaku gerakan.

\section{DAFTAR PUSTAKA}

APJII (2016). Infografis Penetrasi dan Perilaku Pengguna Internet di Indonesia Survey 2016. Asosiasi Penyelenggara Jasa Internet Indonesia.

Barton, David \& Lee, Carmen. 2013. "Language Online: Investigating Digital Texts and Practices". Oxford: Routledge.

Brown, C \& Mayisela, T. (2015). CILT Position Paper: Digital literacies. CILT, University of Cape Town.

Buckingham, David. (2006). "Defining Digital Literacy: What do young people need to know about digital media?". Digital Kompetanse." 4-2006. 1. 263276.

Flew, Terry. (2004). "New Media: An Introduction ( $2^{\text {nd }}$ Edition)". Oxford, New York: Oxford University Press.

Head, Alison J. \& Eisenberg, Michael B. (2009). "How College Students Seek Information in the Digital Age?" Project of Information Literacy, University of Washington.

Jones, Rodney H. \& Hafner, Christoph A. 2012. "Understanding Digital Literacies: A practical introduction". Oxford: Routledge.

Koltay, Tibor. (2011). "The media and the literacies: media literacy, information literacy, digital literacy". Media, Culture, \& Society. 33(2). 211-221

Lankshear, Colin \& Knobel, Michelle. (2008). "Digital Literacies: concepts, policies and practices". New York: Peter Lang.

Potter, James W. 2014. Media Literacy (7 $7^{\text {th }}$ ed.). Thousand Oaks, California: Sage Publication.

ALA Digital Literacy Taskforce, 2011. http:// connect.ala.org/files/94226/what $\% 20$ is\%2odigilit\%20\%282\%29.pdf

IITE Policy Brief, May 2011. http://iite. unesco.org/pics/publications/en/ files/3214688.pdf 
OECD, 2012. Programme for International Student Assessment (PISA). https:// www.oecd.org/pisa/pisaproducts/ PISA\%202012\%2oframework\%20 e-book_final.pdf

CCSU, 2016. The World's Most Literate Nation (WMLN). http://webcapp.ccsu. edu/?news $=1767 \&$ data 